\title{
Ujian Nasional, Dulu, Kini dan yang Akan Datang: Tinjauan Normatif
}

\author{
Muntholi'ah \\ Institut Agama Islam Negeri Walisongo Semarang \\ Email: lilikmuntholiah@yahoo.com
}

\begin{abstract}
The policy of the National Examination (UN) continues to get criticism from education experts, practitioners, as well as various elements of society. With the problems happen in the implementation of National Examination, it can be affirmed that the impacts of its implementation are more harmful than the objectives to be achieved. Considering the imbalances and disadvantages of the National Examination implementation, the government through the Ministry of Education should have to be more thoughtful and immediately review the policy comprehensively. Thus, the purpose of education should be tailored to the interests of Indonesia, which is stated and defined in the the National Education Law No. 20/2003 on National Education System Chapter II, Article 3.
\end{abstract}

Keywords: comprehensive, evaluation principles, education quality, hypocrite, instruments validity

\begin{abstract}
Abstrak
Kebijakan Ujian Nasional (UN) terus menuai kritik dari para pakar dan praktisi pendidikan serta berbagai kalangan masyarakat. Melihat banyaknya permasalahan dan carut-marut dalam pelaksanaan Ujian Nasional dapat ditegaskan bahwa dampak dari penyelenggaraan UN lebih banyak mudaratnya dari pada tujuan yang ingin dicapai. Menilik berbagai ketimpangan dan kemudaratan yang ditimbulkan akibat pelaksanaan UN, maka seyogianya pemerintah melalui Kemendiknas harus bersikap lebih bijaksana dan segera mengkaji ulang kebijakan UN secara komprehensif. Dengan demikian maka tujuan pendidikan yang hendak dicapaipun disesuaikan dengan kepentingan bangsa Indonesia, yang sekarang ini tujuan pendidikan tersebut dirumuskan dalam Undang-Undang Nomor 20 tahun 2003 tentang Sistem Pendidikan Nasional (UU sisdiknas) BAB II pasal 3.
\end{abstract}

Kata kunci: komprehensif, prinsip evaluasi, kualitas pendidikan hipokrit, validitas instrumen 


\section{A. Pendahuluan}

Sejak zaman penjajahan, bangsa Indonesia telah memiliki kepedulian terhadap pendidikan. Namun pelaksanaannya masih diwarnai oleh kepentingan politik kaum penjajah, sehingga tujuan pendidikan yang hendak dicapaipun disesuaikan dengan kepentingan mereka.

Setelah bangsa Indonesia memproklamirkan kemerdekaannya, bangsa Indonesiapun menunjukan kepeduliannya terhadap pendidikan. Hal itu terbukti dengan menempatkan usaha untuk mencerdaskan kehidupan bangsa sebagai tujuan nasional bangsa Indonesia. Sebagaimana tertulis dalam pembukaan Undangundang Dasar 1945 alenia ke 4, yang berbunyi:

Kemudian daripada itu untuk membentuk suatu pemerintahan negara Indonesia yang melindungi segenap bangsa Indonesia dan seluruh tumpah darah Indonesia dan untuk memajukan kesejahteraan umum, mencerdaskan kehidupan bangsa, dan ikut melaksanakan ketertiban duniayang berdasarkan kemerdekaan perdamaian abadi dan keadilan sosial, maka disusunlah kemerdekaan kebangsaan Indonesia itu dalam suatu susunan negara republik Indonesia yang berkedaulatan rakyat dengan berdasarkan kepada: Ketuhanan yang maha esa, kemanusiaan yang adil dan beradab, Persatuan Indonesia, dan kerakyatan yang dipimpin oleh hikmat kebijaksanaan dalam permusyawaratan perwakilan, serta dengan mewujudkan suatu keadilan sosial bagi seluruh rakyat Indonesia. ${ }^{1}$

Dengan demikian maka tujuan pendidikan yang hendak dicapaipun disesuaikan dengan kepentingan bangsa Indonesia, yang sekarang ini tujuan pendidikan tersebut dirumuskan dalam Undang-Undang Nomor 20 Tahun 2003 tentang Sistem Pendidikan Nasional (UU sisdiknas) BAB II pasal 3 yang berbunyi sebagai berikut:

Pendidikan Nasional berfungsi mengembangkan kemampuan dan membentuk watak serta peradaban bangsa yang bermartabat dalam rangka mencerdaskan kehidupan bangsa, bertujuan untuk berkembangnya potensi peserta didik agar menjadi manusia yang beriman dan bertaqwa kepada Tuhan Yang Maha Esa, berakhlaq mulia, sehat, berilmu, cakap, kreatif, mandiri, dan menjadi warga negara yang demokratis serta bertanggung jawab. ${ }^{2}$

\footnotetext{
${ }^{1}$ Kitab Undang-undang Dasar 1945.

${ }^{2}$ Undang Undang Nomor 20 Tahun 2003 tentang Sistem Pendidikan Nasional.
} 
Pendidikan merupakan salah satu sektor penting dalam pembangunan di setiap negara. Menurut Undang-Undang No. 20 Tahun 2003 pendidikan merupakan usaha sadar dan terencana untuk mewujudkan suasana belajar dan proses pembelajaran agar peserta didik secara aktif mengembangkan potensi dirinya untuk memiliki kekuatan spiritual keagamaan, pengendalian diri, kepribadian, kecerdasan, akhlak mulia, serta keterampilan yang diperlukan dirinya, masyarakat, bangsa dan negara. ${ }^{3}$ Untuk mencapai tujuan pendidikan yang mulia ini disusunlah kurikulum yang merupakan seperangkat rencana dan pengaturan mengenai tujuan, isi, dan bahan dan metode pembelajaran. Kurikulum digunakan sebagai pedoman dalam penyelenggaraan kegiatan pembelajaran untuk mencapai tujuan pendidikan yang telah ditentukan. Untuk melihat tingkat pencapaian tujuan pendidikan, diperlukan suatu bentuk evaluasi.

Kalau kita perhatikan dunia pendidikan, kita akan mengetahui bahwa setiap jenis atau bentuk pendidikan pada waktu-waktu tertentu selama satu periode pendidikan, selalu mengadakan evaluasi. Artinya pada waktu-waktu tertentu selama satu periode pendidikan, selalu mengadakan penilaian terhadap hasil yang telah dicapai, baik oleh pihak terdidik maupun oleh pendidik.

Evaluasi pendidikan merupakan salah satu komponen utama yang tidak dapat dipisahkan dari komponen pendidikan. Namun perlu dicatat bahwa tidak semua bentuk evaluasi dapat dipakai untuk mengukur pencapaian tujuan pendidikan yang telah ditentukan. Informasi tentang tingkat keberhasilan pendidikan akan dapat dilihat apabila alat evaluasi yang digunakan sesuai dan dapat mengukur setiap tujuan. Alat ukur yang tidak relevan dapat mengakibatkan hasil pengukuran tidak tepat bahkan salah sama sekali.

Evaluasi pendidikan juga merupakan ranah teknologi pendidikan. ${ }^{4}$ Ranah ini tentu tidak terpisahkan dengan ranah lain yaitu desain (design), pengembangan (development), penggunaan (utilization) dan pengelolaan (management). Oleh karena itu dalam menentukan sebuah mekanisme evaluasi perlu melihat ranah yang lain sehingga dapat dihasilkan hasil belajar atau potret "nilai" peserta belajar secara komprehensif.

\footnotetext{
${ }^{3}$ Undang Undang Nomor 20 ...

${ }^{4}$ Seels, Barbara B. and Richey, Rita C. Instructional Technology: The Definition and Domains of the Field. (Wahington: AECT, 1994).
} 
Definisi Teknologi Pendidikan tahun 2004 lebih luas mencakup studi dan praktik etis memfasilitasi pembelajaran dan meningkatkan kinerja dengan menciptakan, menggunakan dan mengelola proses teknologi yang cocok dan sumberdaya ${ }^{5}$. Di dalam fasilitasi tersebut masuk unsur evaluasi dalam rangka memastikan bahwa hasil belajar telah tercapai sesuai dengan tujuan yang telah ditetapkan.

Namun pada tingkat praktik, ternyata pandangan teoretis ini tidak atau belum terealisasi dengan baik. Salah satu masalah yang terkait dengan teori, model dan keputusan dalam pelaksanaan evaluasi (yang merupakan ranah teknologi pendidikan) adalah keputusan penyelenggaraan Ujian Nasional (UN) bagi semua jenjang pendidikan sekolah.

\section{B. Kebijakan}

Kebijakan Ujian Nasional (UN) mulai diberlakukan sejak tahun 2002. UN saat itu bertujuan menggantikan model evaluasi akhir belajar yang dikenal dengan Evaluasi Tahap Akhir Nasional (EBTANAS). Dipandang perlu untuk diuraikakan secara detail tentang sejarah kebijakan evaluasi secara nasional yang pernah berlaku di Indonesia untuk menambah wawasan kita yang mempunyai atensi dalam dunia pendidikan kita, sebagai berikut:

1. Periode tahun 1950-1960-an. Pada periode ini ujian kelulusan disebut dengan ujian penghabisan dan diadakan secara nasional serta soal-soal dibuat oleh Departemen Pendidikan, Pengajaran dan Kebudayaan. Soal-soal yang diujikan berbentuk essai dan hasil ujian diperiksa di pusat rayon.

2. Periode tahun 1965 - 1971. Pada periode ini, semua mata pelajaran diujikan dalam hajatan yang disebut ujian negara. Bahan ujian dibuat oleh pemerintah pusat dan berlaku untuk seluruh wilayah di Indonesia. Waktu ujian juga ditentukan oleh pemerintah pusat. Peserta ujian disilang antar-sekolah sehingga dalam satu ruang ujian, peserta yang berasal dari sekolah yang sama paling banyak 2 sampai dengan 3 orang (untuk Sekolah Dasar). Pelaksana dan penentu kelulusan ujian adalah pemerintah. Pada Ujian Negara maupun Ujian Sekolah

5 Januszewski, dkk., Educational Technology: A Definition with Commentary. (New York: Lawrence Erlbaum Associates. 2004). 
(Nilai Raport) ditetapkan nilai kelulusan adalah di atas 4. Artinya, siswa yang bernilai 4 ke bawah tidak lulus atau tidak naik kelas.

3. Periode tahun 1972 - 1979. Pada periode ini, pemerintah memberi kebebasan untuk setiap sekolah atau kelompok sekolah menyelenggarakan ujian sendiri. Pembuatan soal dan penilaian dilakukan masing-masing sekolah atau kelompok sekolah. Pemerintah hanya menyusun pedoman dan panduan yang bersifat umum. Penentuan kelulusan berdasarkan hasil Ujian Sekolah. Penentu kelulusan adalah sekolah.

4. Periode tahun 1980 - 2001. Pada Periode ini mulai diselenggarakan ujian akhir nasional yang disebut EBTANAS (Evaluasi Belajar Tahap Akhir Nasional). Model ujian akhir ini menggunakan dua bentuk, yaitu EBTANAS untuk mata pelajaran tertentu dan EBTA untuk mata pelajaran nonEBTANAS. EBTANAS dikoordinasi oleh pemerintah pusat dan EBTA dikoordinasi oleh pemerintah provinsi. Dalam EBTANAS dikembangkan sejumlah perangkat soal yang "paralel" untuk setiap mata pelajaran, dan penggandaan soal dilakukan di daerah. Penyelenggara ujian adalah sekolah dan pemerintah. Pada awalnya hasil EBTANAS tidak dijadikan penentu kelulusan. Namun tahun berikutnya dijadikan salah satu penentu kelulusan walau tidak dijadikan satu-satunya penentu kelulusan sehingga kelulusan bisa mencapai $100 \%$. Penentu kelulusan siswa adalah sekolah, yang ditentukan oleh kombinasi nilai semester I (P), nilai semester II (Q), dan nilai EBTANAS murni (R).

5. Periode tahun 2002 - 2004. Pada periode ini, EBTANAS diganti dengan nama Ujian Akhir Nasional (UAN). Penyelenggara ujian adalah sekolah dan pemerintah. Penentu kelulusan adalah sekolah dengan kebijakan standar kelulusan tiap tahun berbeda-beda. Pada UAN tahun 2002 kelulusan ditentukan oleh nilai mata pelajaran secara individual. Pada UAN tahun 2003 standar kelulusan adalah 3,10 pada setiap mata pelajaran dan nilai rata-rata minimal 6,00. Soal ujian dibuat oleh Depdiknas dan pihak sekolah tidak dapat mengatrol nilai UAN. Para siswa yang tidak/belum lulus masih diberi kesempatan mengulang selang satu minggu sesudahnya. Pada UAN tahun 2004, kelulusan siswa didapat berdasarkan nilai minimal pada setiap mata pelajaran 4,10 dan tidak ada nilai rata- 
rata minimal. Pada mulanya UAN tahun 2004 ini tidak ada ujian ulang bagi yang tidak/belum lulus. Namun setelah mendapat masukan dari berbagai lapisan masayarakat, akhirnya diadakan ujian ulang. Pada UAN 2004 ini terdapat kontroversi tentang Konversi Nilai UAN yang dianggap merugikan siswa-siswa yang pandai dan lebih menguntungkan siswa yang kurang pandai.

6. Periode tahun 2005 - 2010. Pada periode ini, UAN diganti namanya menjadi Ujian Nasional (UN). Penyelenggara ujian adalah sekolah (satuan tingkat pendidikan) dan pemerintah. Penentu kelulusan adalah sekolah (satuan tingkat pendidikan) dengan batas/standar kelulusan nasional, yang setiap tahun berbeda-beda. Pada UN tahun 2005 minimal nilai untuk setiap mata pelajaran adalah 4,25. Pada UN tahun 2005 ini para siswa yang belum lulus pada tahap I boleh mengikuti UN tahap II hanya untuk mata pelajaran yang belum lulus. Pada UN 2005, sesuai janji Mendiknas yaitu tidak ada lagi konversi nilai seperti tahun sebelumnya.

Berkaitan dengan hasil Ujian Nasional tersebut, Depdiknas memberikan kesempatan kepada siswa yang belum lulus Ujian Nasional tahap pertama, mengikuti Ujian Nasional tahap kedua hanya untuk mata pelajaran yang belum lulus. Selain itu, Depdiknas mengeluarkan edaran kepada perguruan tinggi dan SMA/MA/SMK bahwa mereka dapat melakukan penerimaan bersyarat bagi siswa yang belum lulus UN. Artinya bagi siswa yang tidak lulus UN, tetap bisa mengikuti SPMB (Seleksi Penerimaan Mahasiswa Baru). Jika ternyata lulus seleksi masuk di perguruan tinggi, maka haknya bisa dipenuhi apabila telah lulus pada Ujian Nasional tahap kedua.

Untuk tahun pelajaran 2005/2006, pemerintah tidak lagi bertindak sebagai penyelenggara ujian nasional. Wewenang tersebut dilimpahkan kepada Badan Standar Nasional Pendidikan. Tujuan utama pemerintah dalam UN selama ini adalah untuk memetakan mutu pendidikan. Termasuk di dalamnya pemetaan terhadap daya serap siswa terhadap mata pelajaran yang diujikan.

Pada UN tahun 2006 standar kelulusan minimal adalah 4,25 untuk tiap mata pelajaran yang diujikan dan rata-rata nilai harus lebih dari 4,50 dan tidak ada ujian ulang. Pada UN tahun 2007 terdapat dua kriteria kelulusan, yaitu: (1) Nilai 
rata-rata minimal 5,00 untuk seluruh mata pelajaran dengan tidak ada nilai di bawah 4,25; (2) Jika nilai minimal 4,00 pada salah satu mata pelajaran yang diujikan, maka nilai pada dua mata pelajaran lainnya adalah 6,00. Pada UN tahun 2007 ini tidak ada ujian ulang. Bagi yang tidak lulus disarankan untuk mengambil Paket $\mathrm{C}$ untuk meneruskan pendidikan atau mengulang UN tahun depan.

Pada UN tahun 2008 mata pelajaran yang diujikan lebih banyak dari yang semula tiga, pada tahun ini menjadi enam (SMA). Standar kelulusan pada tahun ini terdapat dua kriteria yang hampir sama dengan tahun 2007 hanya saja terdapat penambahan nilai rata-rata untuk seluruh mata pelajaran yang diujikan, yaitu Bahasa Indonesia, Matematika, Bahasa Inggris dan IPA minimal adalah 5,25 dengan tidak ada nilai di bawah 4,25. Penambahan mata pelajaran pada UN tahun 2008 ini karena BSNP mendapat masukan, bahwa ada ketidakseimbangan tingkat keseriusan antara mata pelajaran yang di-UN-kan dan yang tidak.

Pada tahun 2010, pelaksanaan ujian terdiri atas Ujian Nasional Utama dan Ulangan. Selain itu, mulai tahun pelajaran 2008/2009, pemerintah menyelenggarakan Ujian Akhir Sekolah Berstandar Nasional untuk SD/MI/SDLB.

7. Periode tahun 2011. Pemerintah dan Badan Standar Pendidikan Nasional telah siap dengan formula baru penilaian kelulusan siswa dari satuan pendidikan. Untuk itu, pelaksanaan ujian nasional tahun ajaran 2010/2011 hanya dilaksanakan satu kali pada bulan Mei 2011. Penilaian kelulusan antara UN dan hasil belajar di sekolah tidak lagi saling memveto, namun bisa saling membantu. Untuk itu, penilaian UN digabung dengan nilai dari sekolah. Kelulusan peserta didik sebagaimana tercantum dalam Permendiknas Nomor 45 Tahun 2010 tentang Kriteria Kelulusan Peserta Didik pada Sekolah Menengah Pertama/Madrasah Tsanawiyah, Sekolah Menengah Pertama Luar Biasa, Sekolah Menengah Atas/Madrasah Aliyah, Sekolah Menengah Atas Luar Biasa, dan Sekolah Menengah Kejuruan Tahun Pelajaran 2010/2011. Pasal 5 menyebutkan bahwa peserta didik dinyatakan lulus US/M SMP/MTs, SMPLB, SMA/MA, SMALB, dan SMK apabila peserta didik telah memenuhi kriteria kelulusan yang ditetapkan oleh satuan pendidikan berdasarkan perolehan Nilai S/M. 
Nilai S/M sebagaimana dimaksud diperoleh dari gabungan antara nilai US/M dan nilai rata-rata rapor semester 1, 2, 3, 4, dan semester 5 untuk SMP/MTs dan SMPLB dengan pembobotan $60 \%$ (enam puluh persen) untuk nilai US/M dan $40 \%$ (empat puluh persen) untuk nilai rata-rata rapor. Nilai S/M sebagaimana dimaksud diperoleh dari gabungan antara nilai US/M dan nilai rata-rata rapor semester 3, 4, dan semester 5 untuk SMA/MA, SMALB dan SMK dengan pembobotan $60 \%$ (enam puluh persen) untuk nilai US/M dan 40\% (empat puluh persen) untuk nilai rata-rata rapor. ${ }^{6}$

Dalam Permendiknas Nomor 45 Tahun 2010 tentang Kriteria Kelulusan Peserta Didik, Pasal 6 menyebutkan bahwa kelulusan peserta didik dalam UN ditentukan berdasarkan NA. NA diperoleh dari nilai gabungan antara Nilai S/M dari mata pelajaran yang diujinasionalkan dan Nilai UN, dengan pembobotan $40 \%$ (empat puluh persen) untuk Nilai S/M dari mata pelajaran yang diujinasionalkan dan $60 \%$ (enam puluh persen) untuk Nilai UN. Peserta didik dinyatakan lulus UN apabila nilai rata-rata dari semua NA sebagaimana dimaksud mencapai paling rendah 5,5 (lima koma lima) dan nilai setiap mata pelajaran paling rendah 4,0 (empat koma nol). ${ }^{7}$

Selanjutnya Pasal 7 menyebutkan bahwa kelulusan peserta didik dari satuan pendidikan ditetapkan oleh setiap satuan pendidikan melalui rapat dewan guru berdasarkan kriteria kelulusan: (1) menyelesaikan seluruh program pembelajaran; (2) memperoleh nilai minimal baik pada penilaian akhir untuk seluruh mata pelajaran yang terdiri atas: (a) kelompok mata pelajaran agama dan akhlak mulia; (b) kelompok mata pelajaran kewarganegaraan dan kepribadian; (c) kelompok mata pelajaran estetika, dan (d) kelompok mata pelajaran jasmani, olah raga, dan kesehatan; (3) lulus US untuk kelompok mata pelajaran ilmu pengetahuan dan teknologi; dan (4) lulus UN. Kelulusan ditentukan oleh Satuan Pendidikan berdasarkan hasil rapat Dewan Guru dengan memperhatikan nilai akhlaq mulia. Untuk tahun 2011, nilai murni (UN) digunakan untuk penentuan nilai kelulusan masuk Perguruan Tinggi.

${ }^{6}$ Permendiknas Nomor 45 Tahun 2010 tentang Kriteria Kelulusan Peserta Didik.

${ }^{7}$ Permendiknas Nomor 45 Tahun 2010 ...., 


\section{Permasalahan}

Dengan melihat perkembangan ujian nasional di atas, dapat kita tarik benang merah bahwa UN mengalami berbagai perubahan dalam mekanisme penyusunan dan pelaksanaan serta penentuan pemberian arti terhadap hasilnya. Hal ini, menurut pandangan kelompok kami, menunjukkan bahwa konsep dan penerapan UN ternyata masih mengalami semacam trial and error. Idealnya sebuah kebijakan ditetapkan melalui telaahan objek formal dan uji publik. Apakah memang benar bahwa untuk mengetahui hasil belajar dapat diketahui dari sebuah alat tes. Apakah instrumen evaluasi yang lain tidak perlu dipergunakan, seperti pengamatan (observasi), uji keterampilan. Sepertinya tahapan ini dalam menentukan kebijakan UN tidak sepenuhnya dilalui. Hal ini terlihat dari indikator banyaknya permasalahan yang timbul dari pelaksanaan UN mulia dari penolakan dari beberapa pihak sampai dengan permasalahan etika penyelenggaraannya.

Argumentasi Pemerintah bahwa UN adalah sebagai salah satu cara untuk mengetahui tingkat penguasaan materi pelajaran secara nasional memang masuk akal. Dengan adanya UN, diharapkan mutu pendidikan Indonesia meningkat dan "compatible" secara nasional sehingga dapat diprediksi sekaligus dibandingkan antara siswa yang ada di kota-kota yang berbeda di seluruh tanah air karena telah mengikuti UN dengan satu standar penilaian. Namun sebagai suatu proses, UN harus memperhatikan unsur lain dalam proses pendidikan, dan Pemerintah telah menerbitkan aturan tersebut Permendiknas No. 41 tahun 2007 tentang Standar Proses untuk Satuan Pendidikan Dasar dan Menengah).

Namun kenyataannya di lapangan banyak sekali permasalahan yang timbul mulai dari segi administrasi (distribusi yang terkesan amburadul, risiko kebocoran soal), maupun pedagogis. Banyak peserta didik yang frustasi bahkan di antaranya sampai nekat melakukan pelanggaraan dengan berbagai cara (mencontek, meminta jawaban melalui SMS, dll) karena merasa tertekan dan cemas yang berlebihan takut tidak lulus.

Ini menunjukkan bahwa Ujian Nasional (UN) tidak sesuai dengan prinsip-prinsip evaluasi pendidikan dan telah mengesampingkan aspek paedagogis dalam pendidikan. Ujian Nasional (UN) telah membuat peserta didik banyak kehilangan kesempatan untuk mengembangkan cipta, rasa dan karsa dalam proses pembelajaran. 
Ujian Nasional (UN) juga telah mengaburkan tujuan pendidikan nasional yang ingin dicapai seperti tertuang dalam UU No 20 Tahun 2003.

UAN berfungsi sebagai alat pengendali mutu pendidikan secara nasional, pendorong peningkatan mutu pendidikan secara nasional, bahan dalam menentukan kelulusan peserta didik, dan sebagai bahan pertimbangan dalam seleksi penerimaan pada jenjang pendidikan yang lebih tinggi. UAN merupakan salah satu bentuk evaluasi belajar pada akhir tahun pelajaran yang diterapkan pada beberapa mata pelajaran yang dianggap "penting", walaupun masih ada perdebatan tentang mengapa mata pelajaran itu yang penting dan apakah itu berarti yang lain tidak penting. Benarkah bahwa matematika, IPA, dan Bahasa Inggris merupakan tiga mata pelajaran yang paling penting?

Pertanyaan yang muncul adalah apakah sistem evaluasi dalam bentuk UN dapat menjawab semua informasi yang diperlukan dalam pencapaian tujuan? Apakah UN dapat memberikan informasi tentang keimanan dan ketakwaan peserta didik terhadap Tuhan Yang Maha Esa? Apakah UN dapat menjawab tingkat kreativitas dan kemandirian peserta didik? Apakah UN dapat menjawab sikap demokratis anak? Dapatkah UAN memberikan semua informasi tentang tingkat ketercapaian tujuan pendidikan yang telah ditetapkan tersebut?

Evaluasi seharusnya dapat memberikan gambaran tentang pencapaian tujuan sebagaimana yang tertuang dalam UndangUndang No. 20 Tahun 2003. Evaluasi seharusnya mampu memberikan informasi tentang sejauh mana kesehatan peserta didik. Evaluasi harus mampu memberikan tiga informasi penting yaitu penempatan, mastery, dan diagnosis. Penempatan berkaitan dengan pada level belajar yang mana seorang anak dapat ditempatkan sehingga dapat menantang tetapi tidak frustasi? Mastery berkaitan dengan apakah anak sudah memiliki pengetahuan dan kemampuan yang cukup untuk menuju ke tingkat berikutnya? Diagnosis berkaitan dengan pada bagian mana yang dirasa sulit oleh anak? ${ }^{8}$ UN yang dilakukan hanya dengan tes akhir pada beberapa mata pelajaran tidak mungkin memberikan informasi

${ }^{8}$ McNeil, John D. Curriculum A Comprehensive Introduction. (Boston: Little, Brown and Company, 1977), hlm.134-135. 
menyeluruh tentang perkembangan peserta didik sebelum dan setelah mengikuti pendidikan.

Dalam Keputusan Mendiknas No. 153/U/2003 terdapat ketidaksinambungan antara tujuan, fungsi, dan bentuk ujian. Pertama, bahwa pelaksanaan UN bertujuan untuk mengukur pencapaian hasil belajar peserta didik melalui pemberian tes. Dari pernyataan tersebut muncul beberapa pertanyaan antara lain:

1. Dapatkah tes yang dilaksanakan di bagian akhir tahun pelajaran memberikan gambaran tentang perkembangan pendidikan peserta didik?

2. Dapatkah tes tersebut memperhatikan proses belajar mengajar dalam keseharian?

3. Dapatkah tes tertulis melihat aspek sikap, semangat dan motivasi belajar anak?

4. Dapatkah tes di ujung tahun ajaran menyajikan keterampilan siswa yang sesungguhnya?

5. Bagaimana kalau terjadi anak sakit pada saat mengikuti tes?

6. Apakah hasil tes dapat menggambarkan kemampuan dan keterampilan anak selama mengikuti pelajaran?

Pertanyaan-pertanyaan di atas tidak mudah untuk memperoleh jawabannya bila dengan hanya memberikan tes pada akhir tahun pelajaran. Hasil belajar bukan hanya berupa pengetahuan yang lebih banyak bersifat hafalan, tetapi juga berupa keterampilan, sikap, motivasi, dan perilaku yang tidak semuanya dapat diukur dengan menggunakan tes karena melibatkan proses belajar. Dengan kata lain terjadi pertentangan antara tujuan yang ingin dicapai dengan bentuk ujian yang diterapkan, karena pengukuran hasil belajar tidak bisa diukur hanya dengan memberikan tes di akhir tahun pelajaran saja.

Kedua, tujuan ujian sebagaimana disebutkan dalam Keputusan Mendiknas di atas adalah untuk mengukur mutu pendidikan di tingkat nasional, provinsi, kabupaten, sampai tingkat sekolah. Lagi pertanyaan yang serupa dengan pertanyaanpertanyaan di atas muncul, seperti apakah mutu pendidikan dapat diukur dengan memberikan ujian akhir secara nasional di akhir tahun ajaran? Apalagi bila dihadapkan mutu pendidikan dari aspek sikap dan perilaku siswa, apakah bisa dilihat hanya pada saat sekejap di penghujung tahun? Mutu pendidikan pada tingkat nasional dapat dilihat dengan berbagai cara, tetapi pelaksanaan 
UAN sebagaimana yang dipraktikkan belum menjawab pertanyaan sejauh mana mutu pendidikan di Indonesia, apakah menurun atau meningkat dari tahun sebelumnya. Bahkan terdapat indikasi bahwa soal-soal UN (yang dulu disebut EBTANAS) berbeda dari tahun ke tahun, dan seandainya hal ini benar maka akibatnya tidak bisa dibandingkannya hasil ujian antara tahun lalu dengan sekarang. Selain itu mutu pendidikan tidak mungkin diukur dengan hanya memberikan tes pada beberapa mata pelajaran "penting" saja, apalagi dilaksanakan sekali di akhir tahun pelajaran. Mutu pendidikan terkait dengan semua mata pelajaran dan pembiasaan yang dipelajari dan ditanamkan di sekolah, bukan hanya pengetahuan kognitif saja. UN tidak akan dapat menjawab pertanyaan seberapa jauh perkembangan anak didik dalam mengenal seni, olah raga, dan menyanyi. UN tidak akan mampu melihat mutu pendidikan dari sisi percaya diri dan keberanian siswa dalam mengemukakan pendapat dan bersikap demokratis. Dengan kata lain, UN tidak akan mampu menyediakan informasi yang cukup mengenai mutu pendidikan. Artinya tujuan yang diinginkan masih terlalu jauh untuk dicapai hanya dengan penyelenggaraan UN.

Ketiga, ujian bertujuan untuk mempertanggungjawabkan penyelenggaraan pendidikan kepada masyarakat. Adalah ironis kalau UN dipakai sebagai bentuk pertanggungjawaban penyenggaraan pendidikan, karena pendidikan merupakan satu kesatuan terpadu antara kognitif, afektif, dan psikomotor. Selain itu pendidikan juga bertujuan untuk membentuk manusia yang berakhlak mulia, berbudi luhur, mandiri, cerdas, dan kreatif yang semuanya itu tidak dapat dilihat hanya dengan penyelenggaraan UN. Dengan kata lain, UN belum memenuhi syarat untuk dipakai sebagai bentuk pertanggungjawaban penyelenggaraan pendidikan kepada masyarakat.

Jika dihubungkan dengan kurikulum, maka UN juga tidak sejalan dengan salah satu prinsip yang dianut dalam pengembangan kurikulum yaitu "diversifikasi kurikulum". Artinya bahwa pelaksanaan kurikulum disesuaikan dengan situasi dan kondisi daerah masing-masing. Kondisi sekolah di Jakarta dan kota-kota besar tidak bisa disamakan dengan kondisi sekolah-sekolah di daerah perkampungan, apalagi di daerah terpencil. Kondisi yang jauh berbeda mengakibatkan proses belajar mengajar juga berbeda. Sekolah di lingkungan kota relatif lebih baik karena 
sarana dan prasana lebih lengkap. Tetapi di daerah-daerah pelosok keberadaan sarana dan prasarana serba terbatas, bahkan kadang jumlah guru pun kurang dan yang ada pun tidak qualified akibat ketiadaan. Kebijakan penerapan UN untuk semua sekolah di Indonesia telah melanggar prinsip tersebut dan mengakibatkan ketidak adilan karena ibarat mengetes atletik tingkat pelatnas yang setiap hari dilatih dengan segala sarana dan prasarana termasuk pelatih yang memadai dengan atletik kampung yang memiliki sarana seadanya. Tentu saja hasilnya jauh berbeda, tetapi kebijakan yang diambil adalah menyamakan mereka.

Pelaksanaan UN hanya pada beberapa mata pelajaran yang dianggap "penting" juga memiliki permasalahan tersendiri. Benarkah hanya matematika, bahasa Indonesia yang merupakan mata pelajaran penting? Bagaimana kalau ada anak yang memiliki bakat untuk melukis, apakah itu berarti bahwa pelajaran seni jelas merupakan pelajaran penting bagi dia? Bagaimana juga dengan anak yang bercita-cita menjadi olahragawan yang berarti bahwa pelajaran olah raga merupakan pelajaran yang penting bagi dia? Kalau begitu kata "penting" di sini untuk siapa? Pelaksanaan UN pada beberapa mata pelajaran akan mendorong guru untuk cenderung mengajarkan mata pelajaran tersebut, karena yang lain tidak akan dilakukan ujian nasional. Hal ini dapat berakibat terkesampingnya mata pelajaran lain, padahal tidak semua anak senang pada mata pelajaran yang diujikan. Akibat dari kondisi ini adalah terjadi peremehan terhadap mata pelajaran yang tidak dilakukan pengujian.

Beberapa orang berpendapat bahwa UN bertentangan dengan kebijakan otonomi daerah sebagaimana diatur dalam UndangUndang No. 32 Tahun 2004. Hal ini dapat dipahami sebagai berikut. Kebijakan UN dilaksanakan bersamaan dengan dikeluarkannya kebijakan otonomi daerah. Selain itu pada saat yang sama juga dikenalkan kebijakan otonomi sekolah melalui manajemen berbasis sekolah. Evaluasi sudah seharusnya menjadi hak dan tanggung jawab daerah termasuk sekolah, tetapi pelaksanaan UN telah membuat otonomi sekolah menjadi terkurangi karena sekolah harus tetap mengikuti kebijakan UN yang diatur dari pusat. Selain itu UN berfungsi untuk menentukan kelulusan siswa. Padahal pendidikan merupakan salah satu bidang yang diotonomikan, kecuali sistem dan perencanaan pendidikan yang diatur secara nasional termasuk kurikulum. Di sisi lain, dengan adanya 
kebijakan otonomi sekolah yang berhak meluluskan siswa adalah sekolah melalui kebijakan manajemen berbasis sekolah. UN telah dijadikan alat untuk "menghakimi" siswa, tetapi dengan cara yang tanggung karena dengan memberikan batasan nilai minimal 4.00. Dengan menetapkan nilai serendah itu, maka berarti bahwa standar mutu pendidikan di Indonesia memang ditetapkan sangat rendah. Kalau direnungkan, apa arti nilai 4 pada suatu ujian. Nilai 4 dapat diartikan hanya $40 \%$ dari seluruh soal yang diujikan dikuasai, padahal secara umum pada bagian lain diakui bahwa nilai yang dapat diterima untuk dinyatakan cukup atau baik adalah di atas 6 . Dengan kata lain, UN selain menetapkan standar mutu pendidikan yang sangat rendah telah "menghakimi" semua siswa tanpa melihat latar belakang, situasi, kondisi, sarana dan prasarana serta proses belajar mengajar yang dialami terutama siswa di daerah pedesaan.

Bila dilihat dari sudut kebijakan, kemungkinan hal ini karena lemahnya pengawasan dalam pelaksanaan kebijakan. Hal ini juga bisa disebabkan kerena belum terpenuhinya standar proses yang telah ditetapkan.

\section{Pembahasan}

Untuk menjawab permasalahan di atas, berikut akan dijelaskan komponen yang terkait dengan kebijakan, kelerasan dengan ranah teknologi pendidikan dan alternatif solusi terhadap permasalahan.

1. Kesesuaian antara kebijakan yang ada

Pendidikan sebagai kebutuhan manusia telah dijamin oleh konsitusi (UUD 1945). Setiap warga Negara berhak memperoleh pendidikan yang layak. Pemerintah bahkan wajib menyediakan pendidikan dasar bagi seluruh anak yang telah memenuhi persyaratan. Kesempatan memperoleh pendidikan juga sama bagi setiap warga Negara. Akses pendidikan harus dibuka seluas-luasnya.

Undang-Undang No. 20 Tahun 2003 menyatakan pendidikan "berfungsi mengembangkan kemampuan dan membentuk watak serta peradaban bangsa yang bermartabat dalam rangka mencerdaskan kehidupan bangsa, bertujuan untuk berkembangnya potensi peserta didik agar menjadi manusia yang beriman dan bertakwa kepada Tuhan Yang 
Maha Esa, berakhlak mulia, sehat, berilmu, cakap, kreatif, mandiri, dan menjadi warga negara yang demokratis serta bertanggung jawab" (Pasal 3). ${ }^{9}$

Menurut Keputusan Menteri Pendidikan Nasional No. 153/U/2003 tentang Ujian Akhir Nasional Tahun Pelajaran 2003/2004 disebutkan bahwa tujuan UAN adalah untuk mengukur pencapaian hasil belajar peserta didik melalui pemberian tes pada siswa sekolah lanjutan tingkat pertama dan sekolah lanjutan tingkat atas. Selain itu UAN bertujuan untuk mengukur mutu pendidikan dan mempertanggungjawabkan penyelenggaraan pendidikan di tingkat nasional, provinsi, kabupaten, sampai tingkat sekolah. ${ }^{10}$

Dalam UU telah dicantumkan fungsi dan tujuan pendidikan secara luas, namun evaluasi yang dilaksanakan hanya berupa tes. Tes dalam UN berbentuk multiple choice. Dari bentuknya terlihat ketidaksesuain antara tujuan luhur pendidikan yang termuat dalam UU. Oleh karenanya validitas UN perlu dipertanyakan.

Bila yang dituju adalah kemampuan kognitif, UN dapat dikatakan memiliki validitas yang tinggi, namun pendidikan bukan mengenai kognitif saja; di dalamnya terdapat aspek afektif dan psikomotor. Lalu dengan apa kedua aspek yang terakhir disebut itu dievaluasi.

Selanjutnya karena validitasnya tinggi hanya di ranah kognitif dan kurang di ranah afektif dan psikomotor, maka otomatis hasil UN belum mampu mencerminkan hasil belajar secara komprehensif. Terdapat aspek lain yang tidak dipotret oleh alat tes UN. Kenyataan ini belakangan disadari oleh Pemerintah sehingga aturan main pelaksanaan UN sedikit dimodifikasi. UN bukan lagi penentu kelulusan siswa, namun sebagai salah satu unsur penentu nilai akhir (kelulusan).

Peraturan Menteri Pendidikan Nasional Nomor 74 Tahun 2009 tentang Ujian Akhir Sekolah Berstandar Nasional (UASBN) Sekolah Dasar/Madrasah Ibtidaiyah/Sekolah Dasar Luar Biasa (SD/MI/SDLB) Tahun Pelajaran 2009/2010 dan Nomor 75 Tahun 2009 tentang Ujian Nasional

${ }^{9}$ Undang-Undang No. 20 Tahun 2003.

10 Keputusan Menteri Pendidikan Nasional No. 153/U/2003 tentang Ujian Akhir Nasional Tahun Pelajaran 2003/2004. 
SMP/SMA/SMK Tahun Pelajaran 2009/2010 menyebutkan bahwa hasil UN digunakan sebagai salah satu pertimbangan untuk penentuan kelulusan peserta didik dari program dan/atau satuan pendidikan. Dengan demikian nilai akhir bukan diambil bulat-bulat dari UN dalam menentukan kelulusan. ${ }^{11}$

Adilkah UN bagi siswa? Permasalahan mengenai keadilan akan dibahas lebih rinci dari sudut pandang teknologi pendidikan.

2. Kesesuaian dari Pandangan Teknologi Pendidikan

UN sebagai keputusan Pemerintah bersifat mengikat dan berlaku bagi semua stakeholder yang terkait. Evaluasi pendidikan dengan menggunakan alat tes dalam UN d satu sisi dapat dikatakan belum menyeluruh dalam memotret hasil belajar siswa. Namun karena telah menjadi kebijakan, mau tidak mau perangkat harus menyesuaikan diri.

Dari sudut pandang teknologi pendidikan, evaluasi merupakan bagian yang terpisahkan mulai dari ranah (domain) lainnya mulai dari pengembangan (development), penggunaan (utilization) dan pengelolaan (management). Evaluasi harus mencerminkan bahwa tujuan belajar telah tercapai. Pemerintah telah menentukan tujuan belajar dari setiap mata pelajaran, namun sekolah sebenarnya juga dapat menyesuaikan tujuan belajar dengan konteks belajar setempat sesuai dengan model Kurikulum tingkat Satuan Pembelajaran (KTSP). Hal in dapat membuat strategi belajar berbeda, namun tetap dengan tujuanyang sama (standar isi). Teknologi Pendidikan mendukung sebuah evaluasi yang dilakukan dengan memperhatikan standar isi dan proses karena hal ini menunjukkan paradigma yang holistik dalam pendidikan.

Evaluasi harus mampu menjawab semua informasi tentang tingkat pencapaian tujuan yang telah ditentukan. Pendidikan yang diarahkan untuk melahirkan tenaga cerdas yang mampu bekerja dan tenaga kerja yang cerdas tidak dapat diukur hanya dengan tes belaka. ${ }^{12}$ Untuk itu evaluasi harus

11 Peraturan Menteri Pendidikan nasional Tahun 2009 tentang Ujian Nasional .

12 Soedijarto, Memantapkan Sistem Pendidikan Nasional. (Jakarta: Grasindo, 1993), hlm.17. 
mampu menjawab kecerdasan peserta didik sekaligus kemampuannya dalam bekerja. Sistem evaluasi yang lebih banyak berbentuk tes obyektif akan membuat peserta didik mengejar kemampuan kognitif dan bahkan dapat dicapai dengan cara mengafal saja. Artinya anak yang lulus ujian dalam bentuk tes obyektif belum berarti bahwa anak tersebut cerdas apalagi terampil bekerja, karena cukup dengan menghafal walaupun tidak mengerti maka dia dapat mengerjakan tes. Sebagai konsekuensinya harus dikembangkan sistem evaluasi yang dapat menjawab semua kemampuan yang dipelajari dan diperoleh selama mengikuti pendidikan. Selain itu pendidikan harus mampu membedakan antara anak yang mengikuti pendidikan dengan anak yang tidak mengikuti pendidikan. Dengan kata lain evaluasi tidak bisa dilakukan hanya pada saat tertentu, tetapi harus dilakukan secara komperehensif atau menyeluruh dengan beragam bentuk dan dilakukan secara terus menerus dan berkelanjutan. ${ }^{13}$

Selanjutnya berkaitan dengan proses pembelajaran, dapat disampaikan bahwa menurut Wotruba dan Wright sebagaimana dikutip dalam Miarso terdapat tujuh indikator pembelajaran yang efektif yaitu:

a. Pengorganisasian kuliah yang baik

b. Komunikasi secara efektif

c. Penguasaan dan antusiasme dalam mata pelajaran

d. Sikap positip terhadap peserta didik

e. Pemberian ujian dan nilai yang adil

f. Keluwesan dalam pendekatan pembelajaran, dan

g. Hasil belajar peserta didik yang baik.

Ujian harus adil dengan memberikan akses informasi tentang hal-hal yang akan diujikan di akhir tahapan pendidikan. Peserta didik perlu mengetahui apa saja yang akan diujikan dan setelah itu umpan baliknya juga disampaikan kepada peserta didik. Untuk mengakomodasi berbagai karakter peserta didik, maka bentuk ujian juga harus bervariasi dan dilakukan beberapa kali. Tes yang dilakukan sekali dan

${ }^{13}$ Soedijarto, Memantapkan Sistem ..., hlm. 27-29. 
menentukan nasib peserta didik kurang memenuhi rasa keadilan.

Namun dalam menanggapi masalah UN terkait dengan pembelajaran perlu dilakukan dengan hati hati di praktik lapangan. Banyak proses pembelajaran ditujukan hanya untuk memenuhi keterampilan menjawab soal. Siswa seharusnya belajar tentang ilmu pengetahuan yang mampu mendorong peningkatan kapasitas mereka, namun tidak membuat fenomena apa yang disebut dengan washback effect di mana guru hanya mengajar siswa cara menjawab soal.

3. Alternatif Solusi

Terdapat beberapa alternatif yang dapat ditempuh untuk menengahi permasalahan yang dihadapi saat ini, yaitu:

a. Sejak tahun 2011, hasil UN tidak sepenuhnya dijadikan penentu kelulusan merupakan alternatif yang paling tepat saat ini. Kelulusan ditentukan oleh nilai gabungan, yaitu Nilai Gabungan $=(0,6 \mathrm{x}$ nilai $\mathrm{UN})+(0,4 \mathrm{x}$ nilai sekolah $)$. Namun untuk tahun-tahun berikutnya, hendaknya bobot nilai UN mempunyai rasional tersendiri. Paling tidak jika penetapan bobot didasarkan pada persentase pemenuhan standar input dan proses yang telah dipenuhi pemerintah akan dirasa lebih rasional. Oleh karena itu, setiap tahun bobot Nilai UN ini akan berubah sesuai dengan pemenuhan kewajiban pemerintah atas standar input dan standar prosesnya. Lebih dirasa rasional lagi apabila setiap sekolah bobotnya berbeda disesuaikan dengan seberapa banyak standar input dan proses telah terpenuhi. Konsekuensinya akreditasi sekolah harus dilakukan secara berkelanjutan (minimal 6 bulan sebelum pelaksanaan UN) sebagai dasar penetapan bobot.

b. Hasil UN hanya dijadikan bahan evaluasi pencapaian standar kompetensi lulusan dan dikaitkan dengan pemenuhan standar input dan proses oleh pemerintah. Jadi, Nilai UN sama sekali tidak dikaitkan dengan kelulusan siswa dari satuan pendidikan sebelum pemenuhan standar isi dan proses dipenuhi $100 \%$.

c. Apabila standar input dan standar proses telah terpenuhi dan telah dapat disusun alat ukur yang hasil ukurnya betulbetul mencerminkan standar output, yaitu tujuan 
pendidikan nasional "manusia yang beriman dan bertakwa kepada Tuhan Yang Maha Esa, berakhlak mulia, sehat, berilmu, cakap, kreatif, mandiri, dan menjadi warga negara yang demokratis serta bertanggung jawab" berdasarkan indikator-indikator yang jelas, maka pemerintah berkewajiban melakukan sosialisasi secara menyeluruh kepada stakeholder pendidikan. Penyelenggara pendidikan diberi kebebasan yang penuh untuk ber-improvisasi tentang pengembangan kurikulum, model pembelajaran, sarana dan prasarana asal semuanya mengacu kepada pencapaian tujuan pendidikan nasional di atas. Untuk evaluasi, pemerintah menyelenggarakan Ujian Nasional yang sepenuhnya dijadikan penentu kelayakan lulusan. Jadi, bisa berupa sertifikasi kompetensi lulusan pada setiap jenjang pendidikan.

\section{E. Kesimpulan}

Berdasarkan pendahuluan, permasalahan dan pembahasan tersebut di atas, penulis mencoba meninjau UN sebagai suatu kebijakan yang harus ditaati oleh para stakeholder. Sebuah kebijakan lahir dari sebuah pemikiran. Penentu kebijakan tentu telah memikirkan baik buruk hasil keputusan. Dari uraian di atas dapat disimpulkan hal-hal sebagai berikut:

1. UN memang penting namun perlu peningkatan baik dari segi kebijakan, isi maupun proses.

2. Bukti empiris menunjukkan bahwa banyak terdapat kelemahan dalam penyelenggaraan UN, namun tidak perlu sampai menghapus kebijakan ini, cukup dievaluasi kembali

3. Dari tahun ke tahun Pemerintah berusaha menyempurnakan kualitas UN agar mampu dipergunakan secara menyeluruh dengan hasil sesuai apa yang telah ditetapkan.

\section{Kepustakaan}

Januszewski, dkk. 2004. Educational Technology: A Definition with Commentary. New York: Lawrence Erlbaum Associates.

McNeil, John D. 1977. Curriculum A Comprehensive Introduction. Boston: Little Brown and Company. 
Miarso, Yusufhadi. 2011. Menyemai Benih Teknologi Pendidikan, Jakarta: Kencana Prenada Media Group.

Peraturan Menteri Pendidikan Nasional Nomor 74 Tahun 2009 tentang Ujian Akhir Sekolah Berstandar Nasional (UASBN) Sekolah Dasar/Madrasah Ibtidaiyah/Sekolah Dasar Luar Biasa (SD/MI/SDLB) Tahun Pelajaran 2009/2010.

Peraturan Menteri Pendidikan nasional Nomor 75 Tahun 2009 tentang Ujian Nasional SMP/SMA/SMK Tahun Pelajaran 2009/2010.

Seels, dkk. 1994. Instructional Technology: The Definition and Domains of the Field. Wahington: AECT.

Soedijarto. 1993. Menuju Pendidikan Nasional Yang Relevan dan Bermutu. Jakarta: Balai Pustaka.

Soedijarto. 1993. Memantapkan Sistem Pendidikan Nasional, Jakarta: Grasindo.

Undang Undang Nomer 20 Tahun 2003 tentang Sistem Pendidikan Nasional 